\title{
DEFINING SOCIAL SUSTAINABILITY AND SOCIALLY CONSCIOUS TOURIST IN SUSTAINABLE TOURISM DEVELOPMENT
}

\author{
Agusta Ika Prihanti Nugraheni $^{\text {ab }}$, Tri Kuntoro Priyambodo ${ }^{a c} *$, Bayu Sutikno ${ }^{\text {a }}$, \\ Hendrie Adji Kusworo ${ }^{a}$ \\ ${ }^{a}$ Tourism Studies Program, Graduate School of Universitas Gadjah Mada,Yogyakarta, \\ Indonesia \\ ${ }^{b)}$ Economics and Business Departement, Vocational Schools of Gadjah Mada University, \\ Yogyakarta, Indonesia \\ ${ }^{c}$ Center for Tourism Studies, Universitas Gadjah Mada, Yogyakarta, Indonesia \\ *Corresponding Author: mastri@ugm.ac.id
}

\begin{abstract}
Sustainable Tourism Development (STD) consists of three dimensions known as environment, economic and social. Although these three dimensions influence each other and cannot stand on their own, and are assumed to be supportive to each other and compatible. However, most studies focus on the environmental and economic dimensions. The social dimension gains less attention and is difficult to attain and operationalize. In order to implement a balanced and successful STD, it needs to be supported by all the tourism stakeholder, including the tourist itself. Therefore, it is necessary to explore the social dimension of STDs and also tourist behavior regarding their social conscious. However, the discussions and understanding of social dimension in STD and socially conscious behavior are still limited. This study aims to define a clear understanding and definition of social dimension of STD which in this study is referred as social sustainability and also a socially conscious tourist. Starting with exploring the aspect of social dimensions formulation and exploring clear definitions of social dimensions of STD's and socially conscious tourist. This study is an exploratory study that aims to explore the boundaries of social dimension of STD and to develop a construct of socially responsible tourist. This study is a qualitative approaches, which includes systematic literature review and Delphi method to obtain expert judgment to gather social dimension aspects of sustainable development, especially in STD. The results of this study are social dimension's aspects of STD, an understanding of social sustainability and socially conscious tourist in STD.
\end{abstract}

Keywords: Social Dimension, Social Sustainability, Sustainable Tourism Development, Systematic literature review

\section{INTRODUCTION}

Environment, economic and social dimension are known as the three dimensions of Sustainable Development (SD), which is also followed by 
Sustainable Tourism Development (STD) concept. According to Böstrom (2012), the relationship between those three dimensions are harmonious and support each other. Conversely, according to several scholars, many studies were still focusing on the environmental and economic dimensions and neglecting the social dimension (Marcuse, 1998; Agyeman, 2008; Bebbington \& Dillard, 2009). Environmental and economic dimensions were generally seen as dimensions that can create synergies and potentials for environmental policies and reforms (Littig $\&$ Grießler, 2005; Bluhdorn \& Welsh, 2007). Furthurmore, several studies suggest that social dimension acquire less attention or not considered at all (Dobson, 1999; Agyeman et.al. 2003; Agyeman \& Evans, 2004; Lehtonen, 2004; Agyeman, 2008; Cuthill, 2009; Dillard et.al., 2009; Böstrom, 2012). Therefore, social dimension is the least developed among the three dimensions of sustainable development (McKenzie, 2004) and it is often discussed as a part of other dimensions.

Sustainable development and sustainable development concept is particularly complex and there is no universal consensus in defining those concepts. However, it gives benefits because the flexibility to interpret those concepts is needed for different framework in different geographical and temporal scales as well as situational context (Boström, 2012). Although considering this work does not provide a clear picture, those frameworks still provides various interpretations which are mostly contrary to reality (Lehtonen, 2004). Thus, social dimension in sustainable development discourse, or concisely social sustainability, is not an absolute or constant concept but a dynamic concept which will always change over time in different places (Dempsey et al, 2011).

Following the World Commission on Environment and Development (WCED) report to the United Nations (UN), social sustainability obtained formal and international status. The report required that social, ecological and economic conditions need to be considered in Sustainable Development (World Commission on Environment and Development, 1987 in Magis \& Shinn, 2009). In the same way of the general concept of sustainable development, social sustainability is an open and debatable (Böstrom, 2012). Studies underlining social sustainability is still limited to the extent that a comprehensive study of this concept is still scarce (Colantonio \& Dixon, 2009). Dempsey et al (2011) acknowledged that literature focusing particularly on social sustainability is somewhat limited, although there are broader literature discussing social capital, social cohesion, social inclusion and social exclusion but in an overlap approach. The approaches of social sustainability concept are still on a practical understanding of plausibility and current political agendas and have not been grounded on theory (Littig \& Grießler, 2005). Social sustainability currently is not treated as an equally constitutive component of sustainable development but it is dealt with in connection with the social implications of environmental politics (OECD, 2001 in Colantonio, 2007; Colantonio \& Dixon, 2009). Dempsey et al (2011) stated that "Social sustainability is a wide-ranging multi-dimensional concept, with the underlying question 'what are the social goals of sustainable development?', which is open to a multitude of answers, with no consensus on how these goals are defined" (Hopwood et al, 2005; Littig and Grießler, 2005).

In achieving a balanced STD, we cannot disregard social dimension and only emphasis on environmental and economic dimension. However, the discussion and understanding of social dimension in STD is still limited. Therefore, we still 
need to define a clear understanding and definition of social dimension of STD or in this study is referred as social sustainability. An explorative study is needed to explore the social dimension of STD. Starting with the formulation of clear definitions of social dimensions of STD's and exploring the aspect of social dimensions.

Another consideration in achieving a balanced STD is the stakeholder participation. A balanced and successful STD can be achieved if all the tourism stakeholder is participating in a responsible way. Many studies focused on government, communities and tourism business responsible behavior in achieving STD, particularly in environmental and economic discussion. However, discussion related to tourists as one of the important stakeholder of tourism is still limited, especially regarding tourist behavior in socially responsible manner. Although several studies discussed about tourist attitude or behavior in relation to corporate social responsibility (CSR), but those studies still focusing on environment and economic dimension, since the understanding of CSR encompass environment, economic and social dimension. Thus, studies in respect of socially tourist behavior is still limited. This research is an exploratory study that aims to explore the boundaries of social dimension of STD and to develop a construct of socially conscious tourist.

\section{METHODOLOGY}

This research is using a qualitative approach, which includes systematic literature review and Delphi method to gather social dimension aspects or themes of sustainable development, especially in sustainable tourism development. To develop a measurement instrument for white tourist scale, a multi-staged development study was conducted in three phases: item generation, scale purification, and scale validation. This study is still in early stage in scale development of socially responsible tourist. Therefore, this study is limited only on the first stage, which is item generation which also involve domain of construct. Systematic literature review is used in item generation to respond to the early stages of the understanding of social dimension of sustainable tourism development and to describe complex, multidisciplinary and fragmented condition that define sustainable tourism development (Farrell \& Twinning-Ward, 2004; Pomering, Noble \& johnson, 2011; Tölkes, 2018). The characteristic of a systematic literature review is the comprehensiveness in the search for relevant publications on a certain theme (Petticrew \& Roberts, 2006). A modified seven pre-defined steps will guide a synthesis and critical appraisal of the literature (Petticrew \& Roberts, 2006), which are research question formulation, defining criteria for literature, literature search, screening, literature content identification, synthesis and review finding dissemination. This method is effective to reveal what is known and what is not yet known about a subject and it is useful in mapping out the breadth of a field (Petticrew \& Roberts, 2006; Pickering \& Byrne, 2014). This method is useful for coping with the given diverse and transdisciplinary knowledge base (Petticrew, 2001; Pickering \& Byrne, 2014). Expert judgement through Delphi method was also used in item generation and especially in determining construct. Questionnaire were distributed to obtain expert judgement regarding the aspect of social dimension of STD in two rounds. 


\section{RESULTS AND DISCUSSION}

As mention earlier, social dimension of STD or in this study is referred as social sustainability. There are already several efforts in defining and proposing typologies and framework of social sustainability, although there is no single definition of social sustainability since their dynamic nature. Most of the social sustainability definitions were developed according to certain discipline or study. Some studies propose conceptual definitions while others definitions offer key themes or aspects of topic that portray social issues relevant to the sustainability discourse (UNSD, 2010).

Tourism is not a mono-discipline subject fields and consists many subject fields and a synergy between different discipline. According to Harding \& Blokland (2014) and Woods (2005), tourism is always connected with other subject fields and have similarity from other subject fields in term of issues being debated, such as in urban and rural studies. Thus, ideas, concepts and frameworks developed in different subject fields can perform as a combination of storage and bridging methods for tourism (Graham, 2005). Each different discipline has the potential function of keeping the summarized results of their research in the form of theoretical notions which can be used by other research areas, thus acting as bridges between different research areas. Therefore, although each scholar doing research according to their own study field to enhance their understanding in their own subject, they also contribute in developing ideas, concepts and frameworks in other fields, including in general social theory (Bramwell, 2015). Moreover, ideas from several different subject fields can be compiled to develop understanding across the social sciences and sometimes between the social sciences and the sciences. Therefore, since there are limited amount of literature regarding social dimension of STD, this study incorporates various literatures from other subject fields aside from tourism literature. Most of the literatures reviewed social dimension's aspect in sustainable development discourse in general, or from marketing, supply chain, geography, housing, forestry literature, urban development and policy perspective. Most of the social dimension's aspect of tourism sustainable development found in organizational literature such as UNWTO and GSTC. UNWTO (2004) and GSTC $(2013 ; 2016 \mathrm{a} ; 2016 \mathrm{~b})$ include aspects of social dimension in their indicator but they do not clearly separate between the three pillars of STD. Social dimension is still seen as a part of either economic and environmental dimension. Moreover, the approach of UNWTO and GSTC in integrating social dimension is more elaborative by not categorizing them into few principles.

The first step in a systematic literature review is determining research questions. In accordance with the objective of this research which is to explore the main aspects of the social dimension of sustainable tourism development related to theoretical concerns about how we understand and define the concept of social sustainability of tourism, the research questions to be answered are what aspects of the social dimension of tourism development that has been discussed in various literatures?

The second step is to determine the criteria that will be used in the literature search. The criteria set out in this study are that the article has to discusses social objectives, social indicators, social pillars, social aspects or social dimensions of sustainable development and/or sustainable tourism development and/or sustainable tourism. The terms determined are: "social pillar", "social dimension", 
"social objectives", "social dimension", "social indicators" of "sustainable tourism development", "sustainable tourism" and/or "sustainable development". One or more of the terminology that is the criterion must be in the title of the article, keywords or abstract of the literature. The scope of this literature review was expanded due to the limited articles related to the sustainable social dimension of tourism in peer-reviewed journals, so that in this research the literature search also included research articles, theses, editorials, working papers, seminar articles, books and chapters in books and written reports in English and Indonesian. This was done in order to get a general picture of the knowledge and basic social dimensions of sustainable tourism development.

The third stage is to search for relevant literature through several electronic databases such as Proquest, Ebsco Host, Science Direct (Elsevier), Emerald and Sage. The electronic database is accessed through the official page of the UGM Library by activating several filters available on the page. In addition, the search is also carried out through scholar.google.com.

The fourth step is to filter and select the literature that has been obtained based on the criteria. The search results with these criteria are 160 literatures. Further screening was carried out and left to 22 literatures, while 138 others were not selected because the literature did not discuss or state the social dimensions of sustainable tourism development or sustainable development and also because of duplication. The nineteenth literature is then used and fully read to assess the content.

The fifth stage was slitghly different from Petticrew and Roberts (2006) and Tölkes (2018), which is a critical appraisal of literature and adapted into the identification of literature content by reading and assessing the content more thoroughly than the previous step. In this stage, we identified the aspects of the social dimension of sustainable tourism development or sustainable development.

In the sixth stage, we synthesize the aspects of the social dimension that have been identified and grouped them based on similarity of meaning or description.

\section{Social Dimension's Aspects of Sustainable Tourism Development}

There are 26 themes or aspects of the social dimension that were synthesized from 22 sources, both from the writings of organizations and individual researchers by screening 160 articles through a systematic review process. These aspects are: "equality, equity, employment, health, social cohesion and inclusion and coherence, education and knowledge, social infrastructure and housing, welfare, community support, accessibility by local residents to key assets, good governance, supporting local entrepreneurs and fair trade by purchasing local, community or social impact, basic needs and quality of life and human well-being, community participation, decent work and better working condition, public safety and security, protecting and enhancing cultural heritage, local identity and assets, human rights (preventing exploitation), demography, hunger and nutrition, economic self-sufficiency, sustaining tourist satisfaction, individual autonomy and realization of personal potential, resources distributions that affect the ability of that society to flourish overtime, and ethics" (Nugraheni et.al, 2019a).

The number of aspects were than reduced through expert judgment. In this study, a panel of judges is given the list of items or aspect of social dimension 
whereby each item is rated by each judge as "clearly representative," "somewhat representative," or "not representative of the construct of interest. The item chosen is when between $75 \%$ and $88 \%$ of the judges involved assign the item to the same construct This method is adapted from Hardesty and Bearden (2004). The result from expert judgment concluded that 16 items are representative or somewhat representative of social dimensions. Those items are: "equality, equity, employment, health, social cohesion, education and knowledge, social infrastructure, support for community, accessibility, good governance, local purchasing, public participation, protecting and enhancing cultural heritage, economic self-sufficient, sustaining tourist satisfaction and ethics".

The systematic literature review also resulted in wide set of definitions of social sustainability derived from various disciplines. Since tourism is a complex discipline and industry which require many disciplines in order to function and operate properly, therefore, those definitions can be considered in developing an understanding of social sustainability in STD.

\section{Social Sustainability Construct}

Social sustainability has many understanding. According to Barbier (1987) and Konning (2002), social sustainability should emphasize on the on the importance of maintaining social values such as equity, culture and social justice, while Sachs (1999) suggested that social sustainability have to rely on basic values, that is equity and democracy. Littig and Grießler (2005) pointed out the importance of 'work' and 'needs' in social sustainability and also stressed the relations between nature and society by stating that "Social sustainability is given, if work within a society and the related institutional arrangements satisfy an extended set of human needs [and] are shaped in a way that nature and its reproductive capabilities are preserved over a long period of time and the normative claims of social justice, human dignity and participation are fulfilled."

Definitions of social sustainability by UNEP and UNWTO (2004) demands supporting human rights, equal opportunities, equal distributions of benefits and the poverty alleviation as well as improving the livelihood of local communities, maintaining and strengthening the community's life support system, preserving traditional cultures and preventing exploitation. While Harris et al (2001) suggest that to be a socially sustainable system it must attain fairness in distribution and opportunity, satisfactory establishment of social services, including education and health, gender equity, political accountability and also participation (Thomsen \& King, 2009). Moreover, using several working definitions from several scholars, Dillard et. al (2009) summarize the concept of social sustainability as "the process that generate social health and well-being now and in the future" and also as "social institutions that facilitate environmental and economic sustainability now and for the future". Another definition stated that social sustainability is "a positive, lifeenhancing condition within communities, and a process with that can achieve that condition" (McKenzie, 2004; Messer \& Kecskes, 2009). This definition considers social sustainability as a condition and also a process and consists of several indicators: equity, diversity, interconnectedness systems and structure, quality of life and democracy and government (McKenzie, 2004). Therefore, a socially sustainable community is equitable, diverse, connected, and democratic and provide a good quality of life (McKenzie, 2004). While four universal principles 
which cover social sustainability is suggested by Magis and Shinn (2009): Human well-being, Equity, democratic government and democratic civil society, Cuthill's (2009) stated a social sustainability frameworks that includes social justice and equity, social infrastructure, engaged governance and social capital.

According to Colantonio and Dixon (2009), social sustainability is associated with how the individuals, communities and societies live with each other and intend to carry out the objectives of the chosen development models. Furthermore, they also have to consider the physical boundaries of their places and planet earth altogether. Colantionio and Dixon (2009) also reasoned that at a more operational level, the development of social sustainability associated with actions in basic thematic fields, consisting of individual and community social spaces, from capacity building and skills development to environmental and spatial imbalances. It means that social sustainability combines the traditional social policy themes and notions such as health and equity with emerging issues in relation to participation, needs, social capital, the economy, the environment and also the principles of happiness, well-being and quality of life. While, the Millennium Development Goals or MDGs (Weingaertner \& Moberg, 2011) consider that social sustainability related to ending extreme poverty and hunger, providing universal primary education, promoting equality of gender and women empowerment, improving maternal health, reducing child mortality, combating HIV/AIDS and malaria, encouraging environmental sustainability and global partnership for development which represent human needs and basic rights that should be enjoyed by every person (Weingaertner \& Moberg, 2011).

Most of the definitions consider equity, social fairness, community participation, human well-being and quality of life and also good governance. Those themes can be elaborated into detail aspects. Colantonio and Dixon (2009) present a more general and comprehensive concept of social sustainability by emphasizing the relationship between societies, communities and individuals living with each other and how they can carry out the objectives of the chosen development models together while also considering the physical boundaries of their places and planet earth as a whole. Therefore, based on this definition, it can be concluded that social sustainability in STD is a condition and a process within tourism that related to how tourism societies, communities, individuals and governments live with each other's and aimed to carry out the objectives of sustainable tourism models and also considering the physical boundaries of the tourism destination and planet earth as a whole. This definition highlighting on the relationship between tourism societies, communities, individuals and governments to achieve a social condition that gives fairness and good quality of life in tourism industry (Nugraheni et.al, 2019b). The social conditions to be achieved is consists of equality, equity, employment, health, social cohesion, education and knowledge, social infrastructure, support for community, accessibility, good governance, local purchasing, public participation, protecting and enhancing cultural heritage, economic self-sufficient, sustaining tourist satisfaction and ethics.

\section{Socially Conscious Tourist}

Tourist is a consumer of tourism product. Therefore, to define what is a socially conscious tourist, it can be started from understanding what is a socially responsible consumer. Consumer Social Responsibility (CnSR) can be defined as a 
conscious and deliberate choice to determine consumption choices based on personal and moral beliefs, which include two basic components (Devinney et. al 2006). The first component is an 'ethical' component related to the importance of non-traditional and social components of products and business processes company; and the second is the 'consumerism' component which suggests that the preferences and desires of a consumer segment are partly responsible for the increasing influence of ethical or social factors (Devinney et. al 2006). A socially responsible consumer will avoid searching, purchasing and using goods and services from companies that can damage or harm the community, therefore they seek goods and services from companies that help the community through buying experience (Mohr, Webb \& Harris, 2001). Another construct related to socially responsible consumer is Social Responsible Consumer Behavior (SRCB) by HaBrookshire and Hodges (2009). SRCB is a behavior of consumers on the acquisition, use, and disposition of products and services based on the desire to minimize or eliminate any effects that are the damaging or harmful and to maximize long-term benefits to society (Ha-Brookshire and Hodges, 2009). Ha-Brookshire and Hodges (2009) adapted the definition to be broader by involving the entire consumption process from the start before purchase (product information search) to product disposal (product evaluation). Furthermore, according to Ha-Brookshire and Hodges (2009), a consumer may only want to behave socially responsible at a certain stage and others want to behave socially responsible at all stages. So that the SRCB can be defined as the behavior carried out by consumers based on its decision to minimize or reduce any negative impacts and maximize any benefits to the community at one stage or several stages of the buying process. The consumption process involves searching for product information, acquisition, use, storage, disposal / stopping using the product and evaluation after stopping using the product (Ha-Brookshire \& Hodges, 2009; Mohr, Webb \& Harris, 2001).

According to Webster (1975 in Mohr, Webb \& Harris, 2001), the socially conscious consumer is a consumer who takes into account the public consequences of personal consumption or who tries to use his purchasing power to bring about social change. From a tourism discourse, Krippendorf (1987, in Stanford, 2006) described a critical tourism consumer as: "someone who chooses the form of travel that does the least harm to the environment, does not disturb the community and culture of the tourist area and from that they get the most benefit. He spends his money on products and services that he already knows are from and who will enjoy the benefits. He uses these principles when choosing accommodation, food and transportation, visiting institutions, buying souvenirs. He planned his trip and he stayed long enough in the place he visited so the experience he gained was very profound ". Another definition according to Sharpley (1994: 84 in Stanford, 2006) states that tourists who are responsible for looking for quality rather than value, are more adventurous, more flexible and more sensitive to the environment and look for more authenticity spacious compared to traditional mass tourists. Other references concern 'good tourists' (Wood \& House, 1991 in Stanford, 2006) and 'green tourists' (Swarbrooke, 1999). Even Swarbrooke (1999) does not provide a definition but describes the responsibilities of tourists.

As mention earlier, tourists are consumers of tourism products. The definitions above give the characteristics of responsible tourists and can be seen similarities, namely that a responsible tourist is someone who supports and protects 
the social and physical environment of the places they visit accompanied by minimizing the negative impacts that can occur on the environment as well as making a positive economic contribution. Therefore, socially conscious tourists are tourists who take into account the public consequences of personal consumption or tourists who try to use their purchasing power to bring social change to the host community. A socially conscious tourist will acquire, use, and dispose tourism products and services based on the desire to minimize or eliminate any effects that are the damaging or harmful and to maximize long-term benefits to society. Socially conscious tourist will avoid buying tourism products from companies that endanger the community and actively looking for tourism products from companies that help the community especially the host community. Furthermore, the behavior of socially conscious tourists will support the process and achievement of social sustainability in STD because they consider most of the social aspects that build social conditions in consuming tourism product

\section{CONCLUSION}

This study contributes to three subfields of the literature: social dimension aspect in Sustainable Tourism Development, social sustainability in Sustainable Tourism Development and socially conscious tourist. We provide an initial understanding of social dimension of sustainable tourism development which is referred as social sustainability in sustainable tourism development and socially conscious tourist. The aspects, that were identified through a systematic literature review, were related to basic needs and quality of life and the need of community participation and good governance to achieve the ideal social condition. Based on expert judgment we eliminate twenty-six aspects into sixteen.

This study concludes that social sustainability in STD is a condition and a process within tourism that related to how tourism societies, communities, individuals and governments live with each other's and aimed to carry out the objectives of sustainable tourism models and also considering the physical boundaries of the tourism destination and planet earth as a whole. This definition highlighting on the relationship between tourism societies, communities, individuals and governments to achieve a social condition that gives fairness and good quality of life in tourism industry with considering equality, equity, employment, health, social cohesion, education and knowledge, social infrastructure, support for community, accessibility, good governance, local purchasing, public participation, protecting and enhancing cultural heritage, economic self-sufficient, sustaining tourist satisfaction and ethics.

This study also explored the understanding of Socially conscious tourists which are tourists who take into account the public consequences of personal consumption or tourists who try to use their purchasing power to bring social change to the host community. A socially conscious tourist will acquire, use, and dispose tourism products and services based on the desire to minimize or eliminate any effects that are the damaging or harmful and to maximize long-term benefits to society. Socially conscious tourist will avoid buying tourism products from companies that endanger the community and actively looking for tourism products from companies that help the community especially the host community. Therefore, the behavior of socially conscious tourists will support the process and achievement 
of social sustainability in STD because they consider most of the social aspects that build social conditions in consuming tourism product

Further research, is still needed to validate those sixteen aspects of social sustainability in STD to develop a well-defined social sustainability definitions in STD and to develop a framework and indicator of socially responsible tourist based on those aspects.

\section{REFERENCES}

Agyeman, J. (2008). Toward a "just" sustainability?. Continuum: Journal of Media \& Cultural Studies 22(6), 751-756.

Agyeman, J. \& Evans, B. (2004). Just sustainability: the emerging discourse of environmental justice in Britain? The Geographical Journal 170(2), 155164.

Agyeman, J., R. Bullard, \& B. Evans (Eds.). (2003). Just Sustainabilities: Development in an Unequal World. London: Earthscan.

Barbier, E.B. (1987). The concept of sustainable economic development". Environmental Conservation 14 (2), 101-110. DOI: 10.1017/S0376892900011449.

Bebbington, J. \& Dillard, J. (2009). Social sustainability: an organizational-level analysis. In J. Dillard, V. Dujon, \& M. King (Eds.), Understanding the Social Dimension of Sustainability (pp. 157-173). New York: Routledge.

Bluhdorn, I. \& Welsh, I. (2007). Eco-politics beyond the paradigm of sustainability: a conceptual framework and research agenda. Environmental Politics 16(2), $185-205$.

Boström, M. (2012). A missing pillar? Challenges in theorizing and practicing social sustainability: introduction to the special issue, Sustainability: Science, Practice and Policy, 8(1), 3-14, doi: 10.1080/15487733.2012.11908080

Bramwell, B. (2015). Theoretical activity in sustainable tourism research. Annals of Tourism Research, 54, $204-218$.

Colantonio, A. (2007). Social sustainability: an exploratory analysis of its definition, assessment methods, metrics and tools, EIBURS Working Paper Series, July.

Colantonio, A \& Dixon, T. (2009). Measuring socially sustainable urban regeneration in Europe, Oxford Institute for Sustainable Development (OISD) School of the Built Environmentiseplor Oxford Brookes University. 
Cuthill, M. (2009). Strengthening the "social" in sustainable development: developing a conceptual framework for social sustainability in a rapid urban growth region in Australia. Sustainable Development 18(6), 362-373.

Dempsey, N., Bramley, G. Power, S \& Brown, C. (2011). The social dimension of sustainable development: defining urban social sustainability, Sustainable Development, 19, 289-300.

Devinney, T.M., Auger, P., Eckhardt, G. \& Birtchnell, T. (2006), The Other CSR: Consumer Social Responsibility.

Dillard, J., Dujon, V \& King, M (Eds.). (2009). Understanding the Social Dimension of Sustainability. New York: Routledge.

Dobson, A. (Ed.). (1999). Fairness and Futurity: Essays on Environmental Sustainability and Social Justice. New York: Oxford University Press.

Farrell, B., \& Twining-Ward, L. (2004). Reconceptualizing tourism. Annals of Tourism Research, 31(2), 274-295.

Graham, E. (2005). Theory and theorizing. In N. Castree, A. Rogers, \& D. Sherman (Eds.). Questioning Geography: Fundamental Debates (pp. 258-273). Oxford: Blackwell. [s:

GSTC. (2013). GSTC destination criteria. https://www.gstcouncil.org/wpcontent/uploads/2013/11/Dest-_CRITERIA_ and_INDICATORS 6-9-14.pdf

GSTC. (2016a). GSTC Industry criteria: Suggested Performance Indicators for Hotels and Accommodations. https://www.gstcouncil.org/wpcontent/uploads/GSTC-Industry-Criteria-for-Hotels-with-indicators-Dec2016.pdf

GSTC. (2016b). GSTC Industry criteria: Suggested Performance Indicators for Tour Operators. https://www.gstcouncil.org/wp-content/uploads/GSTC$\underline{\text { Industry-Criteria-for-Tour-Operators-with-indicators-Dec-2016.pdf }}$

Ha-Brookshire, J.E., \& Hodges, N.N. (2009). Socially Responsible Consumer Behavior?: Exploring Used Clothing Donation Behavior. Clothing \& Textiles Research Journal, 27(3), 179-196, July.

Hardesty, D.M. \& Bearden, W.O. (2004). The use of expert judges in scale development: Implications for improving face validity of measures of unobservable constructs. Journal of Business Research, Elsevier, 57(2), 98107, February.

Harris, M., Timothy, A.W., Gallagher K.P. \& Goodwin, N.R. (eds). (2001). A Survey of Sustainable Development: Social and Economic Dimensions. Washington, D.C. Island Press. 
Harding, A., \& Blokland, T. (2014). Urban theory. A critical introduction to power, cities and urbanism in the 21st century. London: Sage.

Hopwood, B., Mellor, M., \& O’Brien, G. (2005). Sustainable Development: mapping different approaches. Sustainable Development, 13, 38-52.

Koning, J. (2002). Social Sustainability in a globalizing world: context, theory and methodology explored. In More on MOST: Proceedings of an Expert Meeting, Rinsum HJ van, Ruijter A de, Kazancigil A, Alagh YK, Genov N, Koning J, Siebers H, Unesco Centre: Amsterdam.

Krippendorf, J. (1987). Ecological approach to tourism marketing. Tourism Management, 8(2), 174-176.

Lehtonen, M. (2004). The environmental-social interface of sustainable development: capabilities, social capital, institutions. Ecological Economics 49(2), 199-214.

Littig, B. \& Grießler, E. (2005). Social sustainability: a catchword between political pragmatism and social theory. International Journal of Sustainable Development 8(1-2), 65-79.

Magis, K. \& Shinn, C. (2009). Emergent principles of social sustainability. In J. Dillard, V. Dujon, \& M. King (Eds.), Understanding the Social Dimension of Sustainability (pp. 15-44). New York: Routledge.

Marcuse, P. (1998). Sustainability is not enough. Environment and Urbanization 10(2), 103-111.

McKenzie, S. (2004). Social sustainability: towards some definitions. In Hawke Research Institute Working Paper Series, No 27. Magill, South Australia: Hawke Research Institute, University of South Australia.

Messer, W.B., \& Kecskes, K. (2009). Social capital and community: university partnership, in J. Dillard, V. Dujon, and M. King (Eds.), Understanding the Social Dimension of Sustainability, 248-263, New York: Routledge.

Mohr, L.A., Webb, D.J. \& Harris, K.E. (2001). Do consumers expect companies to be socially responsible? The impact of corporate social responsibility on buying behavior, Journal of Consumer Affairs, 35, 45-72.

Nugraheni, A.I.P., Priyambodo, T.K., Sutikno, B., \& Kusworo, H.A. (2019a, September). Social Dimensions' Aspects of Sustainable Tourism Development Analysis: A Systematic Literature Review. Paper presented at International Heritage Tourism Forum, Yogyakarta, Indonesia.

Nugraheni, A.I.P., Priyambodo, T.K., Sutikno, B., \& Kusworo, H.A. (2019b, October). The social dimension of sustainable development: defining tourism social sustainability. Paper presented at International Conference on Engineering, Science and Commerce, Labuan Bajo, NTT, Indonesia. 
Petticrew, M., \& Roberts, H. (2006). Systematic reviews in the social sciences: A practical guide. Malden, MA: Blackwell Publishing. ss:

Pickering, C., \& Byrne, J. (2014). The benefits of publishing systematic quantitative literature reviews for $\mathrm{PhD}$ candidates and other early career researchers. Higher Education Research and Development, 33(3), 534-548.

Pomering, A. A., Noble, G. I. \& Johnson, L. (2011). Conceptualising a contemporary marketing mix for sustainable tourism. Journal of Sustainable Tourism, 19(8), 953-969.

Sachs, I. (1999). Social sustainability and whole development. In: Becker, E., Jahn, T. (Eds.), Sustainability and the Social Sciences. Zed Books and UNESCO, New York, 25-36.

Stanford, D. (2006). Responsible Tourism, Responsible Tourists: What Makes A Responsible Tourist In New Zealand?. Dissertation. Victoria University of Wellington, http://researcharchive.vuw.ac.nz/xmlui/bitstream/handle/10063/367/thesis.p df? sequence $=2$

Swarbrooke, J. \& Horner, S. (1999). Consumer behaviour in tourism, London: Butterworth Heinemann.

Thomsen K. \& King, M.C. (2009). Working out Social Sustainability on the Ground, in J. Dillard, V. Dujon, and M. King (Eds.), Understanding the Social Dimension of Sustainability, 199-210. New York: Routledge.

Tölkes, C. (2018). Sustainability communication in tourism - A literature review. Tourism Management Perspective, 27, 10-21.

UNSD. (2010). The UNSD Website, http://www.un.org/esa/dsd/susdevtopics/sdt index.shtml.

UNWTO. (2004). Indicators of sustainable development for tourism destination: a guidebook. Madrid Spain: World Tourism Organization.

Weingaertner, C. \& Moberg, A. (2011). Exploring Social Sustainability: Learning from Perspectives on Urban Development and Companies and Products, Sustainable Development. doi: http://dx.doi.org/10.1002/sd.536

Woods, M. (2005). Rural geography. Processes, responses and experiences in rural restructuring. London: Sage.

World Commission on Environment and Development. (1987). Our Common Future. United Nations. 